Journal of Jazz Studies vol. 8, no. 1, pp. 82-92 (Spring 2012)

\title{
Terry Teachout's Pops
}

\author{
Michael Cogswell
}

Pops. By Terry Teachout. Boston: Houghlin Mifflin Harcourt, 2009. 475 pp. $\$ 30$.

Louis Armstrong is such a towering figure in the history of Western music that it seems odd that, until the publication of Terry Teachout's Pops, no one had yet written a definitive, narrative biography of Armstrong. Armstrong's first autobiography Swing That Music ${ }^{1}$ (1936), which holds the notable distinction of being the first book about a jazz musician, was heavily edited and partially ghostwritten because the editors apparently did not trust that Armstrong, who had scant formal education, was capable of writing a book. Satchmo: My Life in New Orleans ${ }^{2}$ (1954), Armstrong's second autobiography, is mostly faithful to Armstrong's typescript, the bulk of which is held by the Institute of Jazz Studies with a concluding portion held by the Louis Armstrong House Museum. But as the subtitle implies, it covers Armstrong's life only until 1922, when he left his hometown of New Orleans to join King Oliver's band in Chicago. Robert Goffin's Horn of Plenty: The Story of Louis Armstrong $^{3}$ (1947) is significant for being the first book length biography of Armstrong but is marred by wild assumptions. Hugues Panassié's Louis Armstrong ${ }^{4}$ (1971) is a brief but important work focusing on Armstrong's recordings. Max Jones and John Chilton's Louis: The Louis Armstrong Story ${ }^{5}$ (1971) benefits from the authors' access to many primary sources such as letters and tapes from Armstrong, but suffers from a rambling narrative-it was a labor of love raced into print soon after Armstrong's passing in 1971. James Lincoln Collier's Louis Armstrong: An American Genius ${ }^{6}$ is a misguided, meanspirited, revisionist biography, which, nevertheless, received complimentary reviews from those who just didn't know any better. One who did know better

\footnotetext{
${ }^{1}$ Louis Armstrong, Swing That Music (London: Longmans, Green, and Co., 1936).

${ }^{2}$ Louis Armstrong, Satchmo: My Life in New Orleans (NY: : Prentice Hall, 1954).

${ }^{3}$ Robert Goffin, Horn of Plenty: The Story of Louis Armstrong (New York: Allen, Towne and Heath, 1947).

${ }^{4}$ Hugues Pannassié, Louis Armstrong (New York: Charles Scribner's Sons, 1971).

${ }^{5}$ Max Jones and John Chilton, Louis: The Louis Armstrong Story (Boston: Little Brown, 1971).

${ }^{6}$ James Lincoln Collier, Louis Armstrong: An American Genius (New York: Oxford, 1983).
} copyright by author $(9)\left(\begin{array}{l}\text { Except where otherwise noted, this work is licensed under } \\ \text { http://creativecommons.org/licenses/by-nc-nd/3.0 }\end{array}\right.$ 
was Dan Morgenstern; his blistering review ${ }^{7}$ of Collier's book in the Annual Review of Jazz Studies should be required reading for all jazz history students. Gary Giddins' Satchmo (1988) is a brilliantly insightful exploration of Armstrong's life and achievements. It is a seminal work that helped launch the current renaissance in thought on Louis Armstrong, and it remains one of the books that I first recommend to readers who desire an introduction to Armstrong. But for all its riches, it is not a narrative biography, by which I mean a book that chapter by chapter follows a strictly chronological account of its subject's life. Laurence Bergreen's Louis Armstrong: An Extravagant Life ${ }^{9}$ (1997) is an entertaining and popular biography that misses the mark on many levels; the author, a professional writer who previously wrote a biography of $\mathrm{Al}$ Capone, is more comfortable writing about-as the subtitle impliesArmstrong's gangster managers, his four wives, and his love of marijuana rather than about Armstrong's profound artistry. It is also riddled with mistakes, large and small. Dempsey Travis's self-published The Louis Armstrong Odyssey: From Jane Alley to America's Jazz Ambassador ${ }^{10}$ (1997) is well intentioned and charming, but amateurish. Mike Pinfold's Louis Armstrong ${ }^{11}$ (1987), Ilse Storb's Louis Armstrong'12 (1989), Stefano Zenni's Louis Armstrong: Satchmo, Oltre il Mito del Jazz $z^{13}$ (1995), Scott Allen Nollen's Louis Armstrong: The Life, Music and Screen Career ${ }^{14}$ (2004), and David Stricklin's Louis Armstrong: The Soundtrack of the American Experience ${ }^{15}$ (2010) are handy surveys which recycle biographical information from secondary sources and contribute little new information. Added to the mix are significant books (e.g., Tom Brother's Louis Armstrong: In His Own Words ${ }^{16}$, Louis Armstrong's New

\footnotetext{
${ }^{7}$ Dan Morgenstern, review of Louis Armstrong: An American Genius, by James Lincoln Collier, Annual Review of Jazz Studies 3 (1985): 193-8.

${ }^{8}$ Gary Giddins, Satchmo (New York: Doubleday, 1988).

${ }^{9}$ Laurence Bergreen, Louis Armstrong: An Extravagant Life (New York: Broadway Books, 1997).

${ }^{10}$ Dempsey Travis, The Louis Armstrong Odyssey: From Jane Alley to America's Jazz Ambassador (Chicago: Urban Research Press, 1997).

${ }^{11}$ Mike Pinfold, Louis Armstrong (New York: Universe Books, 1987).

${ }^{12}$ Ilse Storb, Louis Armstrong (Reinbek bei Hamburg: Rowohlt Taschenbuch, 1989).

${ }^{13}$ Stefano Zenni, Louis Armstrong: Satchmo, Oltre il Mito del Jazz (Rome: Nuovi Equilibri, 1995).

${ }^{14}$ Scott Allen Nollen, Louis Armstrong: The Life, Music and Screen Career (Jefferson, NC:

McFarland, 2004).

${ }^{15}$ David Stricklin, Louis Armstrong: The Soundtrack of the American Experience (Chicago: Ivan R. Dee, 2010).

${ }^{16}$ Louis Armstrong, Louis Armstrong, In His Own Words: Selected Writings. Edited by Thomas Brothers (New York: Oxford, 1999).
} 
Orleans $^{17}$, Joshua Berrett's The Louis Armstrong Companion ${ }^{18}$, Michael Meckna's Satchmo: The Louis Armstrong Encyclopedia ${ }^{19}$, and my own Louis Armstrong: The Offstage Story of Satchmo $^{20}$ ) that do not purport to be narrative biographies. Ricky Riccardi's brilliant What a Wonderful World: The Magic of Louis Armstrong's Later Years ${ }^{21}$ (2011) was still in manuscript form and would focus on the final decades of Louis's life. The stage was set for a qualified author to write "the book" on Armstrong. Enter Terry Teachout.

In the interest of full disclosure, I must share that as a professional staff member of the Louis Armstrong House Museum (Curator from 1991-1994 and Director from 1994 to the present), I know most of the authors cited above and have had generous contact with Teachout. Teachout has stated that he first considered writing his Armstrong biography when I mentioned, while showing him through the Armstrong House, that no one had yet authored a proper biography. I don't remember this moment, but it makes sense that I would say it. Subsequently, Teachout performed extensive research in the collections of the Louis Armstrong House Museum and was assisted by Museum staff, including me. Soon after the book's release, the Museum hosted a standing room only book signing, and the Museum still sells the book in its little gift shop. I ask the reader to accept that I can present a disinterested opinion of the book.

Teachout is exceptionally qualified to tackle a biography of Armstrong. He serves as the drama critic for the Wall Street Journal and the chief cultural critic of Commentary. He previously wrote two well-received biographies: All in the Dances: A Brief of Life George Balachine 22 and The Skeptic: A Life of H.L. Mencken. ${ }^{23}$ His essays on American arts and culture have been collected in $A$ Terry Teachout Reader. ${ }^{24} \mathrm{He}$ was a presidential appointee to the National Council on the Arts (2004-2010). His blog, About Last Night, is an entertaining and informative take on the arts in America today. He worked as

\footnotetext{
${ }^{17}$ Thomas Brothers, Louis Armstrong's New Orleans (New York: Norton, 2006).

${ }^{18}$ Joshua Berrett, ed., The Louis Armstrong Companion: Eight Decades of Commentary (New York: Schirmer, 1999).

${ }^{19}$ Michael Meckna, Satchmo: The Louis Armstrong Encyclopedia (Westport, CT: Greenwood, 2004).

${ }^{20}$ Michael Cogswell, Louis Armstrong: The Offstage Story of Satchmo (Portland, OR: Collectors

Press, 2003).

${ }^{21}$ Ricky Riccardi, What a Wonderful World: The Magic of Louis Armstrong's Later Years (New York: Pantheon, 2011).

${ }^{22}$ Terry Teachout, All in the Dances: A Brief of Life George Balachine (Boston: Houghton Mifflin Harcourt, 2004).

${ }^{23}$ Terry Teachout, The Skeptic: A Life of H.L. Mencken (New York: Harper Collins, 2002).

${ }^{24}$ Terry Teachout, $A$ Terry Teachout Reader (New Haven: Yale University Press, 2004).
} 
a jazz bassist in Kansas City for many years before dedicating himself to writing. His book in progress is Mood Indigo: A Life of Duke Ellington. And those are merely the highlights of his career.

Hallelujah! The wonderful news is that Teachout understood the immense challenges of his quest and succeeded commendably. Pops is the most significant new work on Armstrong since Gary Giddins' pioneering Satchmo $0^{25}$ (1988), which helped to launch the renaissance in thought on Armstrong. In the 1980s, Armstrong was still considered by many, if not most, to be a profound 1920's musical innovator who then sold out and became a purveyor of pop songs and vaudeville shtick. The original LP pressing of the Smithsonian Collection of Classic Jazz (1973) includes eight tracks with Armstrong as leader (more selections than any other artist), but none is after 1933, even through Armstrong made splendid recordings and ovation-worthy performances for almost four more decades. Gunther Schuller in The Swing Era (1989) stated that in later decades Armstrong's "performances consisted more and more of clowning, mugging, less and less of trumpet playing, and, of course, more singing" ${ }^{26}$ and decried Armstrong's apparent "need to scratch out a living as a good-nature buffoon, singing 'Blueberry Hill' and 'What a Wonderful World' night after night." ${ }^{27}$ The entry on Armstrong in the first edition of The New Grove Dictionary of Jazz, considered the pre-eminent reference work on jazz, declared that, "his work from this point [i.e., c. 1930] represents a gradual but inexorable decline" and that his performances with the All Stars (1947-1971) were "quite uneven and often replete with showy and well-worn phrases." ${ }^{28}$ Thanks to Giddins, Wynton Marsalis (who used the bully pulpit of Jazz at Lincoln Center to praise Armstrong), Ken Burns, Dan Morgenstern (who has always been a true believer), and several superb re-issues of recordings, by the arrival of the twenty-first century, jazz scholars and even the general public recognized that Armstrong was a brilliant musician in every decade of his career. Pops was written in the wake of that renaissance.

In Pops, all seven decades in Armstrong's life receive appropriate examination. Some previous biographies focus on the early decades and then fizzle out as Armstrong ages. (For example, Bergreen devotes 434 pages to Armstrong's life up until the formation of the All Stars in 1947 and then a scant sixty pages to the remaining twenty-four years.) The imbalance is

${ }^{25}$ Giddins, Satchmo.

${ }^{26}$ Gunther Schuller, The Swing Era: The Development of Jazz, 1930-1945 (New York: Oxford University Press, 1989): 196.

${ }^{27}$ Ibid.

${ }^{28}$ James Lincoln Collier, "Louis Armstrong" in The New Grove Dictionary of Jazz, ed. Barry Kernfeld, 2 vols. (New York: Macmillan Press, 1988). 
understandable, though inexcusable. The early decades provide a compelling narrative: black boy is raised in abject poverty in New Orleans, fires a gun in the street, is sent to reform school, learns to play the cornet, invents the jazz solo, and becomes a star. The later decades are more challenging to capture in story form. Armstrong was a workhorse who followed an almost unceasing schedule of international tours, performances in large and small venues, recording sessions, radio and television appearances, motion picture shoots, and more. He was married four times. Every Armstrong biographer must not only gather and confirm facts but also make sense of it all. Teachout has a wonderful ability to weave a compelling narrative from a mountain of data. For example, Louis's return to New York City in 1929, the flop of the theatrical work Great Day in Philadelphia, its brief reopening in New York City, Louis's subsequent role in Hot Chocolates (which had downtown and uptown incarnations), his relationship with Connie and George Immerman (the mobconnected owners of Connie's Inn), his blossoming friendship and collaboration with Fats Waller, his renditions in the theatre and on record of "Ain't Misbehavin" and "Black and Blue," and the receptions in the press and by the public of these performances, are all presented in a smooth, chronological narrative that makes the interrelationships clear. Examples appear in every chapter, covering every decade. Teachout's ability to place a whirlwind of events in context is masterful and is easy to overlook because it does not draw attention to itself.

Teachout is an impressive researcher. What gives Pops such depth, helping to present a richly evocative portrait of Armstrong, is the breadth and diversity of Teachout's sources, which include oral histories, letters, manuscripts, liner notes, recordings, newspapers, academic periodicals, popular magazines, biographies, jazz histories, blogs ${ }^{29}$ and more. Teachout has stated in interviews that "I was the first person to write a book about Armstrong who came along after [Armstrong's personal] tapes became available to researchers." ${ }^{30}$ This statement is wonderful for promoting the book, but it is not exactly true. The Louis Armstrong Educational Foundation (which administers the Armstrong estate) donated Armstrong's vast personal collection of tapes, photographs, scrapbooks, manuscripts, etc. (what the Museum calls the "Louis Armstrong Collection") to Queens College in 1986, and work to process it began in 1991. When the collections opened to the public in May 1994, more than 200 of Armstrong's 700 home-recorded tapes had been copied and cataloged, with

\footnotetext{
${ }^{29}$ One of Teachout's sources is the incredibly detailed blog by Armstrong scholar Ricky Riccardi, http://dippermouth.blogspot.com.

${ }^{30}$ Transcription of interview with Terry Teachout, http://bigthink.com/ideas/17687.
} 
the rare and unique tapes having been copied first. From 2000-2002, working under a grant from the National Endowment for the Humanities, a full-time audio engineer copied almost all of the remaining tapes. So, many tapes have been available since 1994, and the bulk of the tapes have been available since 2003. (And the Museum continues to deepen and refine the finding aids for all of its collections.) Teachout's achievement is that he is the first researcher to methodically listen to many dozens of Armstrong's home-recorded tapes. Perusing the home-recorded tapes must be done in "real time." It would be nearly impossible for a researcher to skim a candidly recorded, spoken-word audiotape in the same way that he or she might quickly flip through a box of photos or visually scan a letter. (Although all of the tapes are cataloged, only a few have been completely transcribed because transcription is a labor-intensive process.) That Teachout invested the effort to truly listen to tapes, searching for that golden nugget of information, is to his immense credit.

Although Teachout made laudable use of his sources, including primary sources such as Armstrong's home-recorded tapes, no stunningly new revelations ("Michael Jackson was Louis Armstrong's love child!") appear in Pops. One can appropriately wonder if there are substantial revelations yet to be made about one of the most public figures in twentieth-century America. Armstrong was always disarmingly candid in interviews and was one of the most photographed and recorded people on the planet. He wrote two autobiographies and thousands of lengthy, informative letters. The strength of Pops is its ability to tell the entire Armstrong story with penetrating insight and enlightening detail.

The observation that "writing about music is like dancing about architecture," first attributed to humorist Martin Mull, captures the dilemma of every biographer of a great musician. An author does not have to be a schooled musician to write well about music. (To my knowledge, the musical training of Dan Morgenstern and Gary Giddins, two of the most eloquent writers on jazz, is limited to obligatory childhood music lessons.) Teachout, a former professional musician, does a fine job in describing Armstrong's music. His account of one of Armstrong's most celebrated recordings is typical: "West End Blues,' recorded on June 28, starts out with a surprise, an unaccompanied cadenza in which Armstrong snaps out four biting quarter notes by way of fanfare, then vaults upward through a chain of interlocking triplet figures to a fiery high $\mathrm{C}$ embellished with a touch of vibrato." Teachout then goes on to note that "West End Blues" was undoubtedly inspired by Armstrong's love of the bel canto cadenzas of opera and the recordings of Herbert Clark, Sousa's acclaimed cornetist. This observation will not be a 
revelation to the Armstrong scholar, ${ }^{31}$ but it nicely expands the average reader's conception of Armstrong's influences.

If others have already said it better, Teachout judiciously quotes them. Note this description by Charlie Holmes (the accomplished alto saxophonist who backed Armstrong in the Luis Russell Orchestra) of Armstrong's legendary upper register: "Louis was hittin' them notes right on the head and expanding...He wasn't squeakin'... Big broad notes...The higher he went, the broader his tone got-and it was beautiful!" [Ellipses mine.]

Could Teachout have written more about the music? Yes. Monumental recording sessions such as Louis Armstrong Plays W.C. Handy are glossed over without examining what makes the music so important and so memorable. But the book comprises 475 pages, and if Teachout were to examine every musical peak, Pops would be overloaded with an unwieldy accumulation of musical description. And he might be accused - unjustly_of hagiography: how many times may an author state how fabulous the music is? For Armstrong, masterpiece followed masterpiece, year after year.

Must a biographer include notated musical examples? General readers who are not musicians may be intimidated by musical examples and may even decline to read the book, falsely believing that they are not members of the intended audience. On the other hand, without musical examples the biographer is challenged to describe his subject's contributions solely in prose. In the New York Times Book Review of Laurence Bergreen's Louis Armstrong: An Extravagant Life, Teachout observed that, "Revealingly, neither 'West End Blues' nor any other Armstrong solo is reproduced in musical notation. Imagine a biography of Mark Twain that contained no excerpts from his writings!"32 Teachout's comment supplements his contention that Bergreen often struggled, and usually failed, to adequately describe Armstrong's music (a contention with which I agree). Teachout in his own book elected not to include musical examples, but there is no harm done by their omission.

Pops sometimes provides fresh insight into Armstrong's music, such as this statement about Louis in the 1930s:

For all his virtuosity, Armstrong was rarely at his best when playing at fast tempos. It was in ballads, swinging medium-tempo numbers, and the blues that he did his most creative improvising. If he had recorded nothing but

\footnotetext{
${ }^{31}$ See, for example, Joshua Berrett, "Louis Armstrong and Opera," The Musical Quarterly 76, no. 2 (Summer 1992): 216-41.

${ }^{32}$ Terry Teachout, "Top Brass: A Life of Louis Armstrong, the Man Who Changed the Face of Western Music," review of Louis Armstrong: An Extravagant Life, by Laurence Bergreen, The New York Times Book Review (August 3, 1997).
} 
"Star Dust" and "St. Louis Blues," he would still be remembered as the greatest jazz soloist of his time; if he had recorded nothing but "I Got Rhythm" and "New Tiger Rag," he would be remembered only as a highnote specialist with a funny voice.

The passage is perhaps overstated for effect-almost every Armstrong performance in this time period, regardless of tempo or form, displays astonishing virtuosity - but the observation is on point: Armstrong's unrelenting swing is most effective in medium tempos and ballads.

Another challenge facing Armstrong biographers is that Armstrong was so much more than a musical virtuoso. If he had only performed on the trumpet, or even only sang, he would still be in all the music history books today. But he also composed tunes that have become jazz standards, appeared in more than thirty films, was a frequent guest on radio and television, wrote two autobiographies and thousands of lengthy letters, created hundreds of charming collages, and was a philanthropist and a humanitarian. Pops nicely captures all these facets of Armstrong's life.

When the narrative arrives at Armstrong's first appearance on the new medium of television, Teachout provides a succinct but robust observation on the role of television in Armstrong's career. It is one of many examples of Teachout's ability to interpret Armstrong in a broader cultural context.

On November 21, 1948, two months after Milton Berle was installed as the host of Texaco Star Theatre and became the first star of network television, the All Stars made their TV debut on Toast of the Town, a Sunday-night variety show hosted by Ed Sullivan, a Broadway columnist turned tastemaker for the electronic age. The program, renamed the Ed Sullivan Show in 1955, ran without a break until a month before Armstrong's death, and through much of that time he would be a frequent guest, sharing the stage with everyone from Van Cliburn to the Rolling Stones. Nor was Sullivan his only broadcast outlet. Armstrong turned up at one time or another on virtually every variety show that aired on network TV in his lifetime, and it was these appearances that did more than anything else to establish him as an indelible presence in postwar American pop culture. Unlike his movies, television presented him as a star, not a stooge, usually playing and singing in front of an audience, a setting in which he was completely at home...In movies he played a part, on TV he played himself.

Teachout's examination of fascinating, problematic, symbiotic relationship between Armstrong and his long-time manager, Joe Glaser, is fair and thorough. He writes more about Sidney Korshak, the mob-associated attorney 
who eventually had a desk at Associated Booking, Glaser's agency, than any other biographer.

The book includes more than twenty judiciously selected photographs, many published for the first time. Of particular merit is a 1931 snapshot of Louis revisiting his childhood home in Jane Alley. The snapshot comes from the vast photographic holdings - currently more than 15,000 images—of the Louis Armstrong House Museum. Museum staff had identified it as being taken during Armstrong's 1931 tour of the South, but it was Teachout who speculated that it might be Jane Alley and verified the location. A backstage photograph — from the Museum's newly acquired Jack Bradley Collection-of Armstrong and Joe Glaser, speaks volumes on the power-sharing issues of their relationship.

An appendix cites "Thirty Key Recordings." It may be a handy list for the newcomer who plans to download music from iTunes, but every Armstrong fan will be disappointed that a favorite track doesn't appear. The fifty-two pages of end notes are filled with rich detail, and readers who desire more should read every note. A select bibliography and an index conclude the book.

Is there critical information that has been left out of Pops? Is Pops the "final word" on Armstrong? No single book can capture every facet of Louis Armstrong. For example, Teachout mentions Armstrong's hobby of creating collages (an artistic medium closely related to jazz), but Armstrong's collage making has been the subject of an entire book in itself: Steven Brower's Satchmo: The Wonderful World and Art of Louis Armstrong. ${ }^{33}$ Studies such as Brian Harker's Louis Armstrong's Hot Five and Hot Seven Recordings ${ }^{34}$ investigate the music in a depth not possible in a narrative biography. Ricky Riccardi's What a Wonderful World: The Magic of Louis Armstrong's Later Years ${ }^{35}$ focuses on the final decades of Armstrong's life in unsurpassed detail. There are at least three topics not covered in Pops, which might have been. The inclusion of these topics would be perfectly appropriate for a single-volume biography. (See, for example, Robin D.G. Kelley's Thelonious Monk: The Life and Times of an American Original. ${ }^{36}$ ) The list that follows is not a sternly reprimanding accounting of lacunae but merely "a short list of things Michael

\footnotetext{
${ }^{33}$ Steven Brower, Satchmo: The Wonderful World and Art of Louis Armstrong (New York: Abrams, 2009).

${ }^{34}$ Brian Harker, Louis Armstrong's Hot Five and Hot Seven Recordings, Oxford Studies in Recorded Jazz series (New York: Oxford University Press, 2011).

${ }^{35}$ Ricky Riccardi, What a Wonderful World: The Magic of Louis Armstrong's Later Years (New York: Pantheon, 2011).

${ }^{36}$ Robin D.G. Kelley, Thelonious Monk: The Life and Times of an American Original (New York: Free Press, 2009).
} 
Cogswell would still like to know about Louis Armstrong but didn't discover them in Pops."

- Who are Armstrong's ancestors? Is "Daniel" a family name? Does Armstrong's ancestry reveal any precedence for his genius? Tad Jones spent twenty years researching Armstrong's ancestry and his childhood in New Orleans, but died, tragically, before his work could be published. Jones was, to my knowledge, the only researcher who invested the time to peruse slave auction ledgers, property records, arrest records, and other documents with the goal of identifying Armstrong's ancestors and understanding their lives. Plans to complete and to publish Jones's work are underway and the resulting book will reveal much new information.

- How did Armstrong build his virtuosic technique? Yes, he was a genius and was born into this world with extraordinary abilities, physically and mentally. But what was his trajectory from buying a pawnshop cornet as a child to playing in the band of the Colored Waifs Home for Boys at age twelve to playing with the top bands in New Orleans as a teenager (while working on a coal cart and holding down other day jobs) to revolutionizing Western music in his twenties? Such virtuosity is typically achieved only by thousands of hours of daily practice and study. Did he really achieve his stunning technique solely through late night performances in honky-tonks, informal lessons with Joe Oliver, and perhaps occasional practice in a borrowed copy of Arban's Complete Conservatory Method? Did residents of Jane Alley hear young Armstrong practice scales and arpeggios?

- Where did Armstrong live after he left Lil Hardin in Chicago in the late 1920s and before he moved to Queens in 1943? Did he really live out of suitcases and hotel rooms for fifteen years, as some infer? Culver City, California has designated a house as one that Armstrong owned (I have visited it and seen the historical plaque), but its claimed chronology is wildly incorrect. The Museum holds 78-rpm discs, scrapbooks, and other personal objects from the 1910s and 1920s: Armstrong must have been keeping these possessions somewhere. Yes, he was on the road 300 days per year, but he had to have had a place to "hang his hat." He was known to have an apartment in Harlem during the time he was courting Lucille.

These questions wait to be answered in some future work. Armstrong fully deserves a multi-volume biography on a par with H.C. Robbins Landon's 
Haydn: Chronicle and Works. ${ }^{37}$ But for the present, Terry Teachout's Pops stands as the definitive, one-volume, narrative biography of Louis Armstrong.

\section{ABOUT THE CONTRIBUTOR}

MICHAEL COGSWELL has served at the Louis Armstrong House Museum since 1991-first as the founding Curator (1991-1994), and then as Director (1994-present). He has a Bachelor of Arts in Music from the University of Virginia, a Masters in Musicology (with a jazz history emphasis) from the University of North Texas, and a Masters in Library Science from Queens College, CUNY. His writings on Louis Armstrong include Louis Armstrong: The Offstage Story of Satchmo (Portland, OR: Collectors Press, 2003) and the entry on Armstrong in The New Grove Dictionary of Jazz, $2^{\text {nd }}$ edition.

${ }^{37}$ H. C. Robbins Landon, Haydn: Chronicle and Works, 5 vols. (Bloomington: Indiana University Press, 1976-80). 